\title{
PENGARUH WORK-FAMILY CONFLICT TERHADAP KINERJA PERAWAT WANITA DENGAN VARIABEL INTERVENING KOMITMEN ORGANISASIONAL DI RSUD BHAKTI DHARMA HUSADA SURABAYA
}

\author{
Ahmad Hilmy Mubassyir dan Nuri Herachwati \\ Departemen Manajemen Fakultas Ekonomi dan Bisnis Universitas Airlangga \\ Email : ahmadchilmy@yahoo.co.id
}

\begin{abstract}
Women who work and uphold the profession will be more likely to experience conflict, because indirectly he would be having attachment or more concentrate to work and put aside her role as a housewife. A sense that women are more concentrated due to work and put aside domestic affairs, this condition will bring conflicts that arise because they feel neglected work as a housewife in addition also the commitment owned organization, especially among civil servants. Conditions such as this is also the case in the Bhakti Dharma Husada Hospital Surabaya, increasing consumer complaints in the past few years is an indication of a decrease in the performance of nurses and one of them was allegedly caused by conflicting roles experienced by nurses and resources woman in the hospital. This means that in this case the performance achieved is not in line with expectations because of the role that conflict. This study sample is 46 female nurses in Bhakti Dharma Husada Hospital Surabaya which will be reviewed in terms of work-family conflict and its influence on the performance of the organizational commitment owned. The results of analysis with Partial Least Square show that work-family conflict has no direct influence on the performance of nurses. Meanwhile, with the influence of organizational commitment variables inferred indirectly influence more significant. This suggests that organizational commitment to civil servants clearly will affect the performance without regard to work-family conflict undertaken female nurse.
\end{abstract}

Keywords: Work-Family Conflict, Organizational Commitment, Female Nurse Performance

\section{Pendahuluan}

Dalam suatu organisasi, sumber daya manusia bukan hanya sebagai alat dalam produksi tetapi memiliki peran penting dalam kegiatan produksi suatu organisasi. Sumber daya manusia memiliki andil besar dalam menentukan maju atau berkembangnya sutau organisasi. Oleh karena itu, kemajuan suatu organisasi ditentukan pula bagaimana kualitas dan kapabilitas sumber daya manusia yang ada di dalamnya baik pria maupun wanita, 


\section{Ahmad Hilmy Mubassyir Nuri Herachhwati}

terutama untuk layanan jasa kesehatan di RSUD yang notabene lebih banyak terdapat sumber daya manusia wanitanya.

Sumber daya wanita yang secara kodrat sebetulnya tidak diwajibkan untuk bekerja ternyata sekarang ini memiliki kesetaraan derajat dengan pria dalam hal pekerjaan. Tentunya hal tersebut akan memunculkan konflik peran ganda wanita sebagai seorang ibu rumah tangga dan juga sebagai sesorang yang bekerja.

Frone, Rusell \& Cooper (1992) mendefinisikan Konflik Peran Ganda (Work Family Conflict) sebagai bentuk konflik peran dimana tuntutan pekerjaan dan keluarga secara mutual tidak dapat disejajarkan dalam beberapa hal. Tekanan yang dirasakan oleh para wanita yang sudah berkeluarga dirasa lebih tinggi. Karena disamping mereka harus bekerja keras, mereka juga dihadapkan oleh tanggung jawab sebagai ibu rumah tangga. Hal itu akan menyebabkan masalah antara tugas keluarga atau tugas pekerjaan yang ditanggung oleh perawat tersebut.

Wanita yang bekerja dan menjunjung tinggi pada profesinya akan lebih berpotensi mengalami konflik, karena secara tidak langsung dia akan lebih mempunyai keterikatan atau lebih berkonsentrasi kepada pekerjaan dan mengesampingkan perannya sebagai ibu rumah tangga. Munculnya perasaan yang disebabkan wanita yang lebih berkonsentrasi bekerja dan mengesampingkan urusan rumah tangga, kondisi seperti ini yang akan memunculkan konflik yang timbul karena merasa melalaikan pekerjaan sebagai seorang ibu rumah tangga.

Siwi (2005:9) di dalam penelitiannya menyimpulkan bahwa wanita yang bekerja dan menjunjung tinggi pada profesinya akan lebih mengalami konflik peran. Dengan demikian, perubahan komitmen organisasi pada diri karyawan wanita akan berpengaruh pada besar kecil kemungkinan terjadinya konflik peran.

Kondisi seperti hal tersebut juga terjadi di RSUD Bhakti Dharma Husada Surabaya, meningkatnya keluhan konsumen pada beberapa tahun akhir yang merupakan indikasi penurunan kinerja perawat dan disinyalir diakibatkan salah satunya oleh konflik peran yang dialami oleh para perawat dan sumber daya wanita yang ada di RSUD tersebut. Artinya dalam hal ini adalah kinerja yang dicapai tidak sesuai dengan harapan. Rini (2002) dalam penelitiannya mengemukakan bahwa, para wanita yang bekerja dihadapkan sebagai pihak yang mengalami stres lebih tinggi dibandingkan pria. Masalahnya, wanita bekerja menghadapi konflik peran sebagai wanita karir sekaligus ibu rumah tangga. Dengan terjadinya konflik peran di dalam perusahaan, terutama bagi mereka yang sudah 


\section{Jurnal Manajemen Teori dan Terapan \\ Tahun 7. No. 3, Desember 2014}

berkeluarga atau sudah menikah, hal ini akan berdampak kurang baik terhadap kinerja di dalam perusahaan dan terhadap para perawat wanita itu sendiri.

\subsection{Rumusan Masalah}

Berdasarkan latar belakang diatas maka permasalahan yang dapat dirumuskan dalam penelitian ini adalah :

1. Apakah work-family conflict berpengaruh langsung dan signifikan terhadap kinerja perawat wanita di RSUD Bhakti Dharma Husada?

2. Apakah work-family conflict berpengaruh signifikan terhadap kinerja perawat wanita di RSUD Bhakti Dharma Husada Surabaya dengan komitmen organisasional sebagai variabel intervening?

\subsection{Tujuan Penelitian}

Berdasarkan rumusan masalah tersebut maka penelitian ini bertujuan yaitu :

1. Menganalisis pengaruh langsung dan signifikan work-family conflict terhadap kinerja perawat wanita di RSUD Bhakti Dharma Husada Surabaya.

2. Menganalisis pengaruh signifikan antara work-family conflict terhadap kinerja perawat wanita di RSUD Bhakti Dharma Husada Surabaya dengan komitmen organisasional sebagai variabel intervening.

\section{Landasan Teori}

\subsection{Work-Family Conflict}

Work family conflict dapat didefiniskian sebagai bentuk konflik peran dimana tuntutan peran dari pekerjaan dan keluarga secara mutlak tidak dapat disejajarkan dalam beberapa hal. Hal ini biasanya terjadi pada saat seseorang berusahan memenuhi tuntutan peran dalam pekerjaan dan usaha tersebut dipengaruhi oleh kemampuan orang yang bersangkutan untuk memenuhi tuntutan keluarganya atau sebaliknya dimana pemenuhan tuntutan peran dalam keluarga dipengaruhi oleh kemampuan orang tersebut dalam memenuhi tuntutan pekerjaannya (Frone, 2003).

Greenhaus dan Beutell (1985) mendefinisikan konflik pekerjaan-keluarga sebagai bentuk konflik peran dimana tuntutan peran pekerjaan dan keluarga secara mutual tidak dapat disejajarkan dalam beberapa hal. Hal ini biasanya terjadi pada saat seseorang berusaha memenuhi tuntutan peran dalam pekerjaan dan usaha tersebut dipengaruhi oleh kemampuan orang yang bersangkutan untuk memenuhi tuntutan keluarganya atau sebaliknya.

Pemenuhan tuntutan peran dalam keluarga dipengaruhi oleh kemampuan orang tersebut dalam memenuhi tuntutan dengan tekanan yang berasal dari beban kerja yang berlebihan dan waktu seperti pekerjaan yang harus diselesaikan terburu-buru dan deadline sedangkan tuntutan keluarga berhubungan dengan waktu yang dibutuhkan untuk menangani tugas-tugas rumah tangga.

Higgins dan Duxbury (1992) dalam Sandroto, Oktorina, dan Mula (2010), peran di pekerjaan yang dapat mengganggu peran di keluarga dapat berupa: 


\section{Ahmad Hilmy Mubassyir Nuri Herachhwati}

1. Pekerjaan dapat mengurangi intensitas bersama keluarga.

2. Fisik dan emosional sudah amat kelelahan setelah bekerja.

3. Harus menyelesaikan pekerjaan dengan tergesa-gesa setiap harinya. Jadwal libur kerja tidak cocok dengan jadwal libur anggota keluarga lainnya.

4. Mempertanyakan perlunya mengurangi pekerjaan untuk menghabiskan lebih banyak waktu dengan keluarga.

Faktor lain yang menyebabkan work family conflict menurut Smith et al., (2004), Greenhaus et al (2002) dan Netemeyer et al (2006) antara lain dirangkum sebagai berikut:

1. Adanya tuntutan antara pekerjaan dan keluarga.

2. Kesulitan membagi waktu antara pekerjaan dan keluarga.

3. Hal yang ingin dilakukan di rumah terhalang karena pekerjaan.

4. Tekanan pekerjaan membuat sulit untuk memenuhi kebutuhan keluarga.

5. Kewajiban pekerjaan yang sering mengubah rencana bersama keluarga.

6. Lamanya jam kerja sehingga waktu untuk keluarga menjadi berkurang.

7. Faktor emosi dalam satu wilayah menggangu wilayah lain.

8. Tuntutan pekerjaan atau karir yang terlalu berat mengakibatkan kewajiban di rumah menjadi terbengkalai.

Hasil penelitian dari Allen, Herst, Bruck, \& Sutton, (2000) menjelaskan bahwa bukti penting yang berhubungan dengan Konflik Peran Ganda (Work Family Conflict) telah menunjukkan bahwa Konflik Peran Ganda (Work Family Conflict) dikaitkan dengan berbagai pekerjaan (kepuasan kerja, komitmen), nonpekerjaan (kepuasan Kelvarga) dan stres terkait dengan (depresi, kelelahan, stres).

Oomens, Geurts, dan Scheepers, (2007) telah melaporkan bahwa Work Family Conflict dan Family Work Conflict secara negatif berhubungan dengan kesehatan mental. Misalnya, jika seorang pekerja sering dituntut untuk kerja lembur, ini membatasi waktu yang tersedia di rumah, yang mungkin bertentangan dengan tuntutan keluarga (Work Family Conflict) atau, jika seorang anak sakit maka hal ini dapat menempatkan tekanan pada tuntutan pekerjaan (Family Work Conflict).

\section{$2.2 \quad$ Komitmen Organisasional}

Mowday (1982) mendefinisikan komitmen sebagai kekuatan relatif dari identifikasi individu dan keterlibatannya sebagai kekuatan relative dari identifikasi individu dengan organisasi kerja. Mitchell (1982) memandang komitmen sebagai suatu orientasi nilai terhadap kerja yang menunjukkan bahwa individu sangat memikirkan pekerjaannya. Dimana pekerjaan memberikan kepuasan hidup, dan pekerjaan memberikan status bagi individu. 


\section{Jurnal Manajemen Teori dan Terapan \\ Tahun 7. No. 3, Desember 2014}

O'Reilly (1989) menyatakan bahwa komitmen organisasi secara umum dipahami sebagai ikatan kejiwaan individu terhadap organisasi termasuk keterlibatan kerja, kesetiaan dan perasaan percaya pada nilai-nilai organisasi.

(Armstrong, 1999: 183) dalam teorinya menyebutkan bawha komitmen organisasi terdiri dari tiga area keyakinan ataupun perilaku yang ditampilkan oleh karyawan terhadap perusahaan dimana ia bekerja. Ketiga area tersebut adalah :

1 Keyakinan dan penerimaan terhadap organisasi, tujuan, dan nilai-nilai yang ada di organisasi tersebut.

2. Adanya keinginan untuk berusaha sebaik mungkin sesuai dengan keinginan organisasi. Hal ini tercakup di antaranya menunda waktu libur untuk kepentingan organisasi dan bentuk pengorbanan yang lain tanpa mengharapkan personal gain secepatnya.

3. Keyakinan untuk mempertahankan keanggotaannya di organisasi tersebut.

Hellriegel dan Slocum (2004) mengatakan bahwa sumber komitmen organisasi dapat bervariasi dari orang perorang. Komitmen pekerja pada sebuah organisasi ditentukan dari karakteristik individu mereka (contohnya, kepribadian dan sikap), dan bagaimana kesesuaian antara pengalaman awal kerja mereka dengan harapan mereka. Selanjutnya, komitmen organisasi berlanjut dengan dipengaruhi oleh pengalaman kerja, dengan banyak faktor yang sama dengan faktor yang mengarahkan pada kepuasan kerja. Faktor- faktor ini juga memberikan kontribusi pada meningkat atau berkurangnya komitmen organisasi. Faktor-faktor tersebut diantaranya adalah: Penggajian, hubungan dengan supervisor atau rekan kerja, kondisi kerja, kesempatan untuk maju, dan lain-lain.

Menurut Hellriegel dan Slocum (2004) komitmen organisasi cenderung akan menjadi kuat, jika:

1. Individu mengembangkan keterikatan yang mendalam dengan organisasi dan rekan kerja mereka, mereka menghabiskan lebih banyak waktu dengan mereka.

2. Senioritas sering akan membawa keuntungan yang mengarah pada pengembangan sikap kerja yang baik

3. Kesempatan pasar kerja yang berkurang dengan usia, menyebabkan pekerja menjadi lebih kuat melakukan pekerjaan mereka sekarang.

Meyer and Allen's (1990) terdapat tiga komponen model dari komitmen yang merupakan karakteristik komitmen pekerja pada organisasi, yaitu:

1. Affective Commitment: (AC) didefinisikan sebagai emosi attachment yang positif pada organisasi. Pekerja yang memiliki komitmen yang kuat mengidentifikasikan organisasi dan keinginan untuk tetap menjadi bagian dari organisasi.

2. Continuance Commitment: Komitmen individual pada organisasi karena mereka merasa akan kehilangan biaya yang tinggi jika meninggalkan organisasinya. Pekerja ini memiliki komitmen pada organisasi nya karena mereka membutuhkannya. 


\section{Ahmad Hilmy Mubassyir Nuri Herachhwati}

3. Normative Commitment: Komitmen individu terhadap organisasi karena merasa suatu kewajiban. Sebagai contoh, organisasi mungkin sudah menghubungkan berbagai sumber daya dalam melatih pekerja merasakan suatu kewajiban moral, sehingga pekerja yang telah dilatih merasa hutang budi dan harus membayarnya. Pekerja ini memiliki komitmen pada organisasi nya karena merupakan keharusan.

\subsection{Kinerja Karyawan}

Helfert dalam Rivai \& Sagala (2010:604) menjelaskan bahwa kinerja adalah suatu tampilan keadaan secara utuh atas perusahaan selama periode waktu tertentu, merupakan hasil atau perestasi yang dipengaruhi oleh kegiatan operasional perusahaan dalam memanfaatkan sumber-sumber daya yang dimiliki.

Sedangkan Hasibuan (2005:94) menjelaskan kinerja adalah suatu hasil kerja yang dicapai seseorang dalam melaksanakan tugas-tugas yang dibebankan kepadanya yang didasarkan atas kecakapan, pengalaman dan kesungguhan serta waktu.

Menurut Mitchel dalam Sedarmayanti (2001:51), menyebutkan aspek-aspek yang meliputi kinerja yang dapat dijadikan ukuran kinerja seseorang, yaitu sebagai berikut:

1. Kualitas Kerja (Quality of Work)

a. Hasil kerja yang diperoleh

b. Kesesuaian hasil kerja dengan tujuan organisasi

c. Manfaat hasil kerja

2. Ketepatan Waktu (Promptness)
a. Penataan rencana kegiatan/ rencana kerja
b. Ketepatan rencana kerja
c. Ketepatan waktu dalam tugas

3. Inisiatif (Initiative)
a. Pemberian ide/ gagasan dalam berorganisasi
b. Tindakan untuk menyelesaikan permasalahan

4. Kemampuan (Capability)
a. Kemampuan yang dimiliki
b. Keterampilan yang dimiliki
C. Kemampuan memanfaatkan sumber daya atau potensi

5. Komunikasi (Communication)
a. Komunikasi intern (ke dalam) organisasi
b. Komunikasi ekstern (ke luar) organisasi
c. Relasi dan kerjasama dalam pelaksanaan tugas Indikator tersebut menunjukan bahwa




\section{Jurnal Manajemen Teori dan Terapan \\ Tahun 7. No. 3, Desember 2014}

Sedangkan menurut Bernadin dan Russel (2000:213), menjelaskan enam kriteria primer yang digunakan untuk mengukur kinerja :

1. Quality, merupakan tingkat sejauh mana proses atau hasil pelaksanaan kegiatan mendekati kesempurnaan atau mendekati tujuan yang diharapkan.

2. Quantity, merupakan jumlah yang dihasilkan, misalkan jumlah rupiah, jumlah unit, jumlah siklus, kegiatan yang diselesaikan.

3. Timeliness, adalah tingkat sejauh mana suatu kegiatan diselesaikan pada waktu yang dikehendaki dengan memperhatikan kordinasi output lain serta waktu yang tersedia untuk kegiatan lain.

4. Cost effectiviness, adalah tingkat sejauh mana penggunaan daya organisasi (manusia, keuangan, teknologi, material) dimaksimalkan utnuk mencapai hasil tertinggi atau pengurangan kerugian dari setiap unit penggunaan sumberdaya.

5. Need for supervisor, merupakan tingkat sejauh mana seorang dapat melaksanakan suatu fungsi pekerjaan tanpa memerlukan pengawasan seorang supervisor untuk mencegah tindakan yang kurang diinginkan.

6. Interpersonal impact, merupakan tingkat sejauh mana karyawan/pekerja memelihara harga diri, nama baik dan kerjasama di antara rekan kerja dan bawahan.

\subsection{Hipotesis Penelitian}

Berdasarkan pada rumusan masalah yang diajukan, tujuan penelitian, kajian teori, kerangka berpikir maka dapatlah diajukan hipotesis dalam penelitian ini adalah sebagai berikut:

1. Work-family conflict berpengaruh langsung dan signifikan terhadap kinerja perawat wanita di RSUD Bhakti Dharma Husada

2. Work-family conflict berpengaruh signifikan terhadap kinerja perawat wanita di RSUD Bhakti Dharma Husada dengan komitmen organisasional sebagai variabel intervening.

\subsection{Kerangka Berfikir}

Berdasarkan hipotesis sebagaimana diuraikan di atas, maka dapat dikemukakan suatu gambar kerangka berfikir penelitian sebagai berikut:

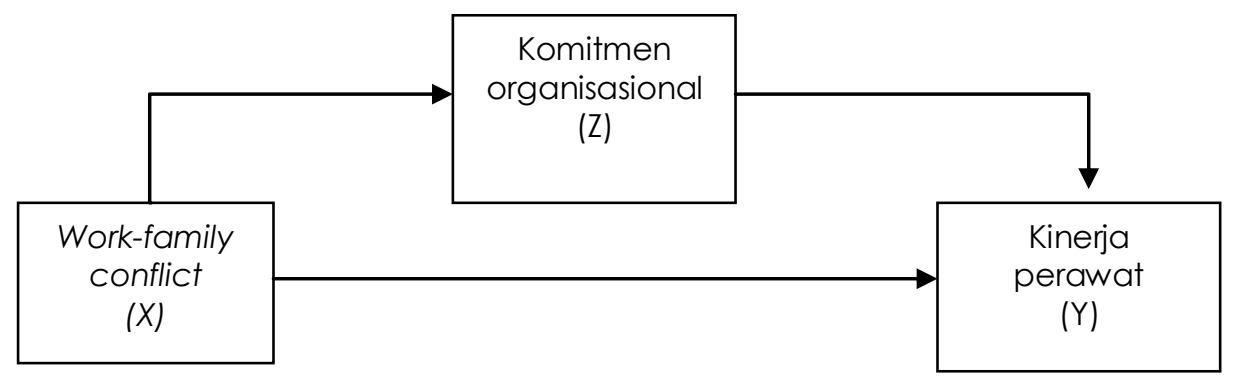

Gambar 2.1 Kerangka Berfikir 


\section{Ahmad Hilmy Mubassyir Nuri Herachhwati}

\section{Metode Penelitian}

Pendekatan penelitian yang digunakan peneliti adalah pendekatan kuantitatif, yaitu pendekatan yang harus menggunakan pengujian hipotesis. Metode pendekatan ini dimulai dengan hipotesis dan teori-teori, dilanjutkan dengan membuat model analisis, identifikasi variable, definisi variable, mengumpulkan data (primer dan sekunder) dan selanjutnya melakukan analisis terhadap hasil penelitian. Untuk memberikan gambaran jelas mengenai variabel yang akan diteliti, maka variabel-variabel yang dianalisis adalah sebagai berikut :
a. Work-Family Conflict (X)
b. Komitmen Organisasional $(Z)$
c. Kinerja Perawat (Y)

\subsection{Definisi Operasional Variabel}

\subsubsection{Work-Family Conflict (X)}

Work-family conflict adalah konflik yang terjadi di tempat kerja yang berpengaruh terhadap kehidupan keluarga (Stone, 2005:384 dalam Choi, 2012). Netemeyer et al., (1996) dalam Latifah (2008) menyebutkan beberapa indikator yang dapat digunakan untuk mengindikasi adanya work-family conflict antara lain:

1. Pekerjaan kantor mengintervensi kehidupan keluarga dan rumah tangga.

2. Tuntutan waktu dalam pekerjaan kantor membawa kesulitan dalam mengurus rumah, keluarga atau tanggung jawab pribadi.

3. Hal yang ingin dilakukan di rumah tidak dapat dilakukan karena tuntutan dari pekerjaan kantor.

4. Pekerjaan menimbulkan stress yang membawa kesulitan untuk memenuhi kewajiban aktivitas bersama keluarga.

5. Terdapat keinginan mengubah rencana untuk waktu beraktivitas bersama keluarga.

\subsubsection{Komitmen Organisasional (Z)}

Berdasarkan Meyer and Allen's (1990) komitmen organisasional adalah kondisi psikologis, yang merupakan karakteristik hubungan pekerja dengan organisasi dan keterlibatan pekerja untuk memutuskan tetap menjadi bagian dari organisasi. Terdapat tiga komponen model dari komitmen yang merupakan karakteristik komitmen pekerja pada organisasi, pengukuran dari variabel komitmen organisasional menggunakan dimensi sebagai berikut:

\section{Affective Commitment}

Berkaitan dengan emosional, identifikasi dan keterlibatan pegawai dalam suatu organisasi, indikator yang digunakan untuk mengukur dimensi ini adalah:

a. Menghabiskan karier merupakan persepsi perawat tentang kesediaan perawat untuk tetap berkarier di Rumah Sakit. 


\section{Jurnal Manajemen Teori dan Terapan \\ Tahun 7. No. 3, Desember 2014}
b. Rasa memiliki merupakan persepsi perawat tentang persamaan memiliki terhadap Rumah Sakit.
c. Pentingnya Rumah Sakit merupakan persepsi perawat tentang arti penting Rumah Sakit bagi perawat .
d. Bangga merupakan persepsi perawat terkait profesinya sebagai perawat.

2. Continuance Commitment

Komitmen yang berdasarkan pertimbangan biaya kerugian yang ditanggung perawat bila perawat meninggalkanorganisi. Indikator yang digunakan untuk mengukur dimensi ini adalah:

a. Rasa berat meninggalkan Rumah Sakit merupakan persepsi perawat tentang perasaannya jika meninggalkan Rumah Sakit.

b. Perubahan merupakan persepsi perawat tentang perubahan dalam kehidupannya jika meninggalkan Rumah Sakit .

c. Keterlibatan merupakan persepsi perawat tentang keterlibatannya dalam Rumah Sakit.

d. Sulit mencari pengganti merupakan persepsi perawat tentang tidak mudah mendapatkan pekerjaan sejenis setelah meninggalkan rumah Sakit.

3. Normative Commitment

Komitmen yang dilandasi oleh pengetahuan normatif tentang tanggung jawab dan kewajiban anggota organisasi, untuk bekerja sebaik-baiknya dalam tempat kerjanya. Indikator yang digunakan untuk mengukur dimensi ini adalah:

a. Ketidakinginan perawat meninggalkan Rumah Sakit merupakan persepsi perawat tentang tingkat ketidakinginan perawat untuk meninggalkan Rumah Sakit.

b. Rasa bersalah merupakan persepsi perawat tentang perasaan bersalah jika harus meninggalkan Rumah Sakit.

c. Loyal merupakan persepsi perawat tentang keinginannya untuk tetap loyal pada rumah Sakit.

d. Tanggung jawab moral merupakan persepsi perawat tentang tanggung jawab moral jika harus meninggalkan Rumah Sakit.

e. Kewajiban untuk setia merupakan persepsi perawat tentang kewajiban untuk setia pada Rumah Sakit.

\subsubsection{Kinerja Perawat $(Y)$}

Hasibuan (2005:94) menjelaskan kinerja adalah suatu hasil kerja yang dicapai seseorang dalam melaksanakan tugas-tugas yang dibebankan kepadanya yang didasarkan atas kecakapan, pengalaman dan kesungguhan serta waktu. Kinerja karyawan merupakan tanggapan pemimpin (atasan) atas proses kerja tertentu dimana perawat akan mencapai hasil kerja tertentu sesuai dengan wewenang dan tanggung jawab yang dinilai 


\section{Ahmad Hilmy Mubassyir Nuri Herachhwati}

oleh atasan perawat secara langsung. indikator yang digunakan menurut Gomes (2000:142) adalah:

1. Quality of works, yaitu kualitas kerja dicerminkan melalui pemenuhan persyaratan selama memeriksa atau melayani pasien.

2. Job knowledge, yaitu pengetahuan kerja yang dimiliki oleh perawat yang sesuai dengan standar pekerjaan dan keterampilan.

3. Creativeness, yaitu dicerminkan melalui ide yang muncul untuk melayani pasien dengan baik.

4. Cooperative, yaitu bekerja sama dengan rekan sekerja dicerminkan melalui mau menolong teman yang tidak dapat melayani pasien dengan baik.

5. Dependability, yaitu tanggung jawab dan kesadaran yang tinggi dalam hal kehadiran dicerminkan melalui perawat tidak pernah absen meskipun waktu kerja tidak menentu.

6. Initiative, perawat mempunyai inisiatif dalam mengatasi permasalahan yang dihadapi pasien.

7. Personal qualities, yaitu keramahtamahan yang dicerminkan oleh perawat saat melayani pasien.

\subsection{Metode Pengumpulan Data}

Sumber data yang digunakan dalam penelitian ini terbagi menjadi dua yaitu data primer dan data sekunder. Data Primer adalah data mengacu pada informasi yang diproleh dari tangan pertama oleh peneliti yang berkaitan dengan vriabel minat untuk tujuan spesifik studi. Data ini diperoleh langsung dengan cara pengamatan secara langsung pada obyek penelitian dan memberikan kuesioner kepada para perawat wanita di Rumah Sakit Dharma Husada Surabaya. Sedangkan data sekunder adalah data yang mengacu pada informasi yang dikumpulkan dari sumber yang telah ada. Data sekunder diperoleh melalui studi kepustakaan, yaitu mengambil data dari buku-buku literatur dan jurnal-jurnal.Studi kepustakaan yang dimaksudkan adalah membaca, mencatat, dan mempelajari hal-hal yang berkaitan erat dan mampu mendukung penelitian ini. Studi kepustakaan ini dilakukan untuk mendapatkan teori-teori untuk dijadikan sebagai landasan teori yang kemudian dapat digunakan untuk menganalisis, menilai, dan menyimpulkan masalah yang akan dibahas serta membantu pengambilan keputusan yang benar dan dapat dipertanggungjawabkan.

\subsection{Prosedur Pengumpulan Data}

Untuk mendapatkan hasil akurat prosedur pengumpulan data harus dilakukan dengan secara sistematis dan efisien, yaitu dengan jalan menyebarkan pertanyaanpertanyaan (kuesioner) kepada responden. Kuesioner adalah "daftar pertanyaan tertulis yang telah dirumuskan sebelumnya yang akan responden jawab, biasanya dalam alternatif yang telah didefinisikan dengan jelas" (sekaran,2006:108). Kuesioner terdiri dari dua bagian, 


\section{Jurnal Manajemen Teori dan Terapan \\ Tahun 7. No. 3, Desember 2014}

bagian pertama terdiri dari pertanyaan tertutup yang mengukur tentang konflik peran, job stress dan kepuasan kerja. Bagian kedua dari kuesioner ini berisi tentang data diri dari responden yang memuat pertanyaan tentang umur, jenis kelamin, status, pendidikan terakhir, lama bekerja RSUD Bhakti Dharma Husada Surabaya, penghasilan setahun dan jabatan responden.

\subsection{Penentuan Populasi dan Sampel}

Menurut Sekaran (2006:121). "populasi mengacu pada keseluruhan kelompok orang, kejadian atau hal minat yang ingin peneliti investigasi". Jumlah total perawat yang ada di RSUD Bhakti Dharma Husada terdapat 152 perawat yakni 52 orang perawat laki - laki dan 100 orang perawat wanita. Diantara 100 orang perawat wanita terdapat 46 orang perawat wanita yang sudah berkeluarga. Sedangkan 54 orang perawat wanita belum berkelvarga. Populasi dalam penelitian ini adalah keseluruhan perawat wanita di RSUD Bhakti Dharma Husada yang sudah berkeluarga. Jumlah populasi dengan kriteria tersebut adalah 46 orang. menurut Sekaran (2006:123),"pengambilan sampel (sampling) adalah proses memilih sejumlah elemen secukupnya dari populasi, sehingga penelitian terhadap sampel adalah pemahaman tentang sifat atau karakteristiknya akan membuat kita dapat menggeneralisasikan sifat atau karakteristik tersebut pada elemen populasi". Oleh karena populasi penelitian telah memenuhi syarat lebih dari $n=30$, maka seluruh populasi dijadikan responden.

\subsection{Teknik Analisis Data}

Pada penelitian dengan menggunakan kuesioner analisis diawali dengan pengujian validitas dan reliabilitas kuesioner serta akan dilanjutkan dengan analisa menggunakan Partial Least Square yang meliputi evaluasi outer model dan inner model. Analisis Partial Least Square dibantu menggunakan software Smart PLS2 M3.

\section{Hasil dan Pembahasan}

4.1 Evaluasi Outer Model

\subsubsection{Convergent Validity}

Hasil dari pengujian convergent validity pada masing-masing variabel penelitian adalah:

Tabel 1

Outer Loading dan t-statistics

\begin{tabular}{|c|c|c|}
\hline Indikator & $\begin{array}{c}\text { Nilai } \\
\text { Outer Loading }\end{array}$ & t-statistics \\
\hline WFC1 & 0,846080 & 14,970152 \\
\hline WFC2 & 0,919998 & 27,124410 \\
\hline WFC3 & 0,870825 & 18,833386 \\
\hline WFC4 & 0,910126 & 33,983210 \\
\hline WFC5 & 0,718598 & 7,017760 \\
\hline KMT1 & 0,822518 & 16,863482 \\
\hline KMT2 & 0,884844 & 23,531395 \\
\hline KMT3 & 0,894047 & 25,031390 \\
\hline KMT4 & 0,895182 & 25,942662 \\
\hline
\end{tabular}




\section{Ahmad Hilmy Mubassyir Nuri Herachhwati}

\begin{tabular}{|c|c|c|}
\hline Indikator & $\begin{array}{c}\text { Nilai } \\
\text { Outer Loading }\end{array}$ & t-statistics \\
\hline KMT5 & 0,846143 & 19,651085 \\
\hline KMT6 & 0,774009 & 12,315319 \\
\hline KMT7 & 0,802285 & 15,146326 \\
\hline KMT8 & 0,831550 & 18,651434 \\
\hline KMT9 & 0,860241 & 22,287149 \\
\hline KMT10 & 0,833612 & 19,833791 \\
\hline KMT11 & 0,832381 & 20,575220 \\
\hline KMT12 & 0,850130 & 20,818442 \\
\hline KMT13 & 0,803080 & 13,682607 \\
\hline KNJ1 & 0,848255 & 15,219572 \\
\hline KNJ2 & 0,831151 & 11,490930 \\
\hline KNJ3 & 0,847897 & 12,730216 \\
\hline KNJ4 & 0,925319 & 29,172914 \\
\hline KNJ5 & 0,936962 & 43,954868 \\
\hline KNJ6 & 0,936960 & 42,742590 \\
\hline KNJ7 & 0,872158 & 19,485796 \\
\hline
\end{tabular}

Berdasarkan Tabel 1 diketahui bahwa nilai outer loading masing-masing indikator pada variabel work family conflict, komitmen organisasional, dan kinerja semuanya bernilai $>0,5$ dengan t-statistics yang juga lebih besar dari 1,96 (>1,96). Dengan demikian berarti indikator-indikator yang digunakan dalam penelitian ini telah memenuhi convergent validity.

Pengujian lain dengan menggunakan AVE adalah sebagai berikut:

Tabel 2

AVE

\begin{tabular}{|l|c|}
\hline \multicolumn{1}{|c|}{ Variabel } & AVE \\
\hline Work Family Conflict & 0,733059 \\
\hline Komitmen Organisasional & 0,708137 \\
\hline Kinerja & 0,785992 \\
\hline
\end{tabular}

Tabel 14 menunjukkan bahwa nilai AVE semua variabel >0,5. Berdasarkan hasil ini maka dapat disimpulkan indikator-indikator variabel dalam penelitian ini juga telah memenuhi convergent validity

\subsubsection{Discriminant Validity}

Hasil pengujian discriminant validity adalah sebagai berikut:

Tabel 3

Akar AVE dan Korelasi Antar Variabel

\begin{tabular}{|l|c|c|c|c|c|}
\hline \multicolumn{1}{|c|}{ Variabel } & AVE & Akar AVE & Work Family Conflict & Komitmen Organisasional & Kinerja \\
\hline $\begin{array}{l}\text { Work Family } \\
\text { Conflict }\end{array}$ & 0,786 & 0,887 & 1,000 & & \\
\hline $\begin{array}{l}\text { Komitmen } \\
\text { Organisasional }\end{array}$ & 0,708 & 0,842 & $-0,437$ & 1,000 & \\
\hline Kinerja & 0,733 & 0,856 & $-0,396$ & 0,732 & 1,000 \\
\hline
\end{tabular}

Berdasarkan Tabel 15 diketahui hampir semua nilai korelasi lebih kecil daripada nilai akar AVE. Hasil ini menunjukkan bahwa indikator-indikator di dalam penelitian ini telah 
memiliki discriminant validity yang baik. Dan hasil pengujian dengan metode lain cross loading adalah:

Tabel 4

Cross Loading

\begin{tabular}{|c|c|c|c|}
\hline \multirow{2}{*}{ Indikator } & \multicolumn{3}{|c|}{ Variabel } \\
\cline { 2 - 4 } & $\begin{array}{c}\text { Work-Family } \\
\text { Conflict }\end{array}$ & $\begin{array}{c}\text { Komitmen } \\
\text { Organisasional }\end{array}$ & Kinerja \\
\hline WFC1 & $\mathbf{0 , 8 4 6 0 8 0}$ & $-0,348499$ & $-0,292552$ \\
\hline WFC2 & $\mathbf{0 , 9 1 9 9 9 8}$ & $-0,319605$ & $-0,359730$ \\
\hline WFC3 & $\mathbf{0 , 8 7 0 8 2 5}$ & $-0,416910$ & $-0,382621$ \\
\hline WFC4 & $\mathbf{0 , 9 1 0 1 2 6}$ & $-0,439230$ & $-0,399347$ \\
\hline WFC5 & $\mathbf{0 , 7 1 8 5 9 8}$ & $-0,324803$ & $-0,228647$ \\
\hline KMT1 & $-0,335533$ & $\mathbf{0 , 8 2 2 5 1 8}$ & 0,556861 \\
\hline KMT2 & $-0,344263$ & $\mathbf{0 , 8 8 4 8 4 4}$ & 0,620438 \\
\hline KMT3 & $-0,302940$ & $\mathbf{0 , 8 9 4 0 4 7}$ & 0,696867 \\
\hline KMT4 & $-0,378554$ & $\mathbf{0 , 8 9 5 1 8 2}$ & 0,665774 \\
\hline KMT5 & $-0,424840$ & $\mathbf{0 , 8 4 6 1 4 3}$ & 0,596208 \\
\hline KMT6 & $-0,255843$ & $\mathbf{0 , 7 7 4 0 0 9}$ & 0,625031 \\
\hline KMT7 & $-0,311147$ & $\mathbf{0 , 8 0 2 2 8 5}$ & 0,582712 \\
\hline KMT8 & $-0,178631$ & $\mathbf{0 , 8 3 1 5 5 0}$ & 0,603317 \\
\hline KMT9 & $-0,319181$ & $\mathbf{0 , 8 6 0 2 4 1}$ & 0,562874 \\
\hline KMT10 & $-0,489086$ & $\mathbf{0 , 8 3 3 6 1 2}$ & 0,525449 \\
\hline KMT11 & $-0,489952$ & $\mathbf{0 , 8 3 2 3 8 1}$ & 0,676861 \\
\hline KMT12 & $-0,485485$ & $\mathbf{0 , 8 5 0 1 3 0}$ & 0,646262 \\
\hline KMT13 & $-0,390341$ & $\mathbf{0 , 8 0 3 0 8 0}$ & 0,616607 \\
\hline KNJ1 & $-0,243566$ & 0,658878 & $\mathbf{0 , 8 4 8 2 5 5}$ \\
\hline KNJ2 & $-0,365384$ & 0,578514 & $\mathbf{0 , 8 3 1 1 5 1}$ \\
\hline KNJ3 & $-0,379738$ & 0,590658 & $\mathbf{0 , 8 4 7 8 9 7}$ \\
\hline KNJ4 & $-0,430100$ & 0,696560 & $\mathbf{0 , 9 2 5 3 1 9}$ \\
\hline KNJ5 & $-0,310957$ & 0,630100 & $\mathbf{0 , 9 3 6 9 6 2}$ \\
\hline KNJ6 & $-0,337950$ & 0,752088 & $\mathbf{0 , 9 3 6 9 6 0}$ \\
\hline KNJ7 & $-0,395643$ & 0,611966 & $\mathbf{0 , 8 7 2 1 5 8}$ \\
\hline & & & \\
\hline
\end{tabular}

Berdasarkan Tabel 4 diketahui bahwa masing-masing indikator pada variabel work family conflict, komitmen organisasional dan kinerja memiliki nilai cross loading terbesar pada variabelnya dibandingkan pada variabel lainnya. Dengan demikian bisa dikatakan indikator-indikator yang digunakan dalam penelitian ini telah memiliki discriminat validity yang baik dalam menyusun variabelnya masing-masing.

\subsubsection{Composite Reliability}

Hasil pengujian composite reliability dapat dilihat pada Tabel 5 sebagai berikut:

Tabel 5

Composite Reliability

\begin{tabular}{|l|c|}
\hline \multicolumn{1}{|c|}{ Variabel } & Composite Reliability \\
\hline Work Family Conflict & 0,962 \\
\hline Komitmen Organisasional & 0,969 \\
\hline
\end{tabular}




\section{Ahmad Hilmy Mubassyir Nuri Herachhwati}

Pada Tabel 5 ditunjukkan bahwa nilai composite reliability untuk variabel work family conflict, komitmen organisasional dan kinerja semuanya telah lebih besar dari 0,70. Dengan demikian dalam model penelitian, masing-masing variabel penelitian telah memenuhi composite reliability.

\subsection{Evaluasi Inner Model}

Hasil evaluasi inner model dalam analisis PLS meliputi penilaian goodness of fit dan pengujian inner weight untuk uji hipotesis penelitian.

\subsubsection{Pengujian Goodness Of Fit}

Penilaian goodness of fit didasarkan pada nilai R-Square yang dihasilkan estimasi partial least square untuk masing-masing jalur. Berdasarkan pengolahan data dengan PLS, dihasilkan nilai R Square sebagai berikut:

Tabel 6

Nilai R Square

\begin{tabular}{|l|c|}
\hline \multicolumn{1}{|c|}{ Variabel } & R Square \\
\hline Komitmen Organisasional & 0,1911 \\
\hline Kinerja & 0,5432 \\
\hline
\end{tabular}

Pada jalur hubungan antara work family conflict terhadap komitmen organisasional dihasilkan nilai R-Square sebesar 0,1911 yang menunjukkan bahwa prosentase keragaman tanggapan mengenai komitmen organisasional yang dikemukakan perawat wanita di RSUD Bhakti Dharma Husada dapat dijelaskan oleh work family conflict nya sebesar 19,11\%, sedangkan sisanya $80,89 \%$ dijelaskan oleh variabel lain selain work family conflict. Sementara itu, untuk nilai R Square untuk kinerja sebesar 0,5432 memiliki arti bahwa prosentase besarnya kinerja perawat wanita pada RSUD Bhakti Dharma Husada yang dapat dijelaskan oleh work family conflict dan komitmen organisasional adalah sebesar $54,32 \%$.

Dari hasil analisis SEM juga dapat dihitung koefisien determinasi secara total (Rm) menggunakan rumus sebagai berikut:

$R^{2} m=1-\left(P_{e}{ }^{2} \times P_{e}{ }^{2}\right)$

dimana:

$\mathrm{R}^{2} \mathrm{~m}=$ Koefisien determinasi total

$\mathrm{P}^{2} \mathrm{ei}=$ Parameter error masing-masing persamaan

$\mathrm{P}_{\mathrm{ei}}=\sqrt{1-R i^{2}}=\left(1-\mathrm{Ri}^{2}\right)^{0.5}$

Dari hasil analisis regresi diperoleh nilai $R_{1}{ }^{2}=0,1911$ dan nilai $R_{2}{ }^{2}=0,5432$, sehingga diperoleh nilai $P_{e 1}$ dan $P_{e 2}$ sebagai berikut:

$P_{e 1}=(1-0,1911)^{0.5}=0,899$

$P_{e 2}=(1-0,5432)^{0.5}=0,676$ 


\section{Jurnal Manajemen Teori dan Terapan \\ Tahun 7. No. 3, Desember 2014}

Didapat nilai koefisien determinasi total sebagai berikut:

$\left.R^{2} m=1-\left(P_{e}\right)^{2} \times P_{e}{ }^{2}\right)$

$R^{2} m=1-\left(0,8992 \times 0,676^{2}\right)=0,630$

Dari hasil perhitungan didapat nilai koefisien determinasi total sebesar 0,630 , yang berarti model PLS yang dikembangkan dapat menjelaskan fenomena yang dikaji sebesar $63,0 \%$, sedangkan sisanya sebesar $37,0 \%$ dijelaskan oleh variabel lain yang tidak dipergunakan di dalam model.

\subsubsection{Inner Weight}

Pengujian hipotesis pengaruh antara work-family conflict $(X)$ terhadap kinerja perawat (Y) melalui komitmen organisasional (Z) sebagai variabel intervening, dapat mengacu pada Baron and Kenny (1986) dalam Beasley (2012), yaitu:

1. Pengaruh langsung variabel bebas terhadap variabel terikat tanpa variabel mediator

(intervening) harus signifikan, yaitu dengan melakukan regresi variabel bebas dengan variabel terikat.

2. Pengaruh variabel bebas terhadap variabel intervening harus signifikan.

3. Pengaruh variabel intervening terhadap variabel terikat harus signifikan.

Pengaruh variabel bebas terhadap variabel terikat masih signifikan setelah variabel intervening dimasukkan (partial mediation) atau pengaruh variabel bebas terhadap variabel terikat tidak signifikan jika ada variabel intervening (full mediation).

Berikut adalah hasil dari analisis SEM dengan menggunakan Partial Least Square:

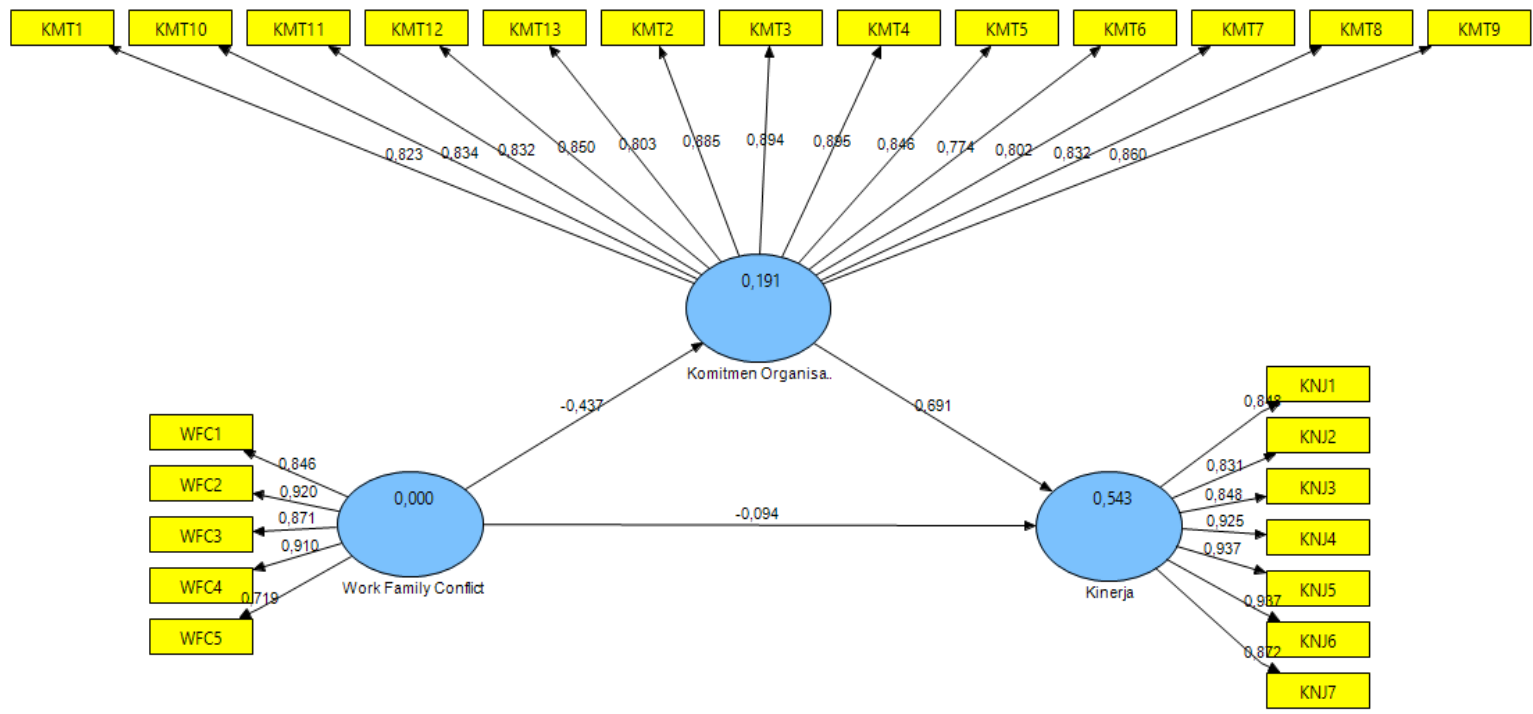

Hasil estimasi pengaruh langsung dan tidak langsung dengan menggunakan metode partial least square didasarkan pada nilai t-statistic yang harus $>1,96$. Berikut adalah hasil estimasi pengaruh langsung:

Tabel 7

Pengaruh Langsung

\begin{tabular}{|l|c|c|c|}
\hline Pengaruh Langsung & $\begin{array}{c}\text { Koefisien } \\
\text { Path }\end{array}$ & $\begin{array}{c}\text { Standart } \\
\text { Error }\end{array}$ & $\begin{array}{c}t- \\
\text { statistic }\end{array}$ \\
\hline
\end{tabular}




\section{Ahmad Hilmy Mubassyir Nuri Herachhwati}

\begin{tabular}{|l|c|c|c|}
\hline Work Family Conflict $\rightarrow$ Komitmen Organisasional & $-0,437$ & 0,116 & 3,742 \\
\hline Komitmen Organisasional $\rightarrow$ Kinerja & 0,690 & 0,078 & 8,870 \\
\hline Work Family Conflict $\rightarrow$ Kinerja & $-0,094$ & 0,095 & 0,988 \\
\hline
\end{tabular}

Hipotesis I

Hasil estimasi pengaruh antara work family conflict terhadap kinerja diketahui besarnya adalah -0,094 dengan nilai t-statistics 0,988. Berdasarkan pada hasil, nilai t-statistics $0,988<1,96$ maka disimpulkan work family conflict tidak memiliki pengaruh yang signifikan terhadap kinerja perawat wanita RSUD Bhakti Dharma Husada. Dengan demikian hipotesis pertama tidak terbukti kebenarannya.

Hipotesis II

Besarnya pengaruh tidak langsung antara work family conflict terhadap kinerja dengan variabel intervening komitmen organisasional didapatkan dengan mengalikan koefisien path pada jalur $X \rightarrow Z$ dan $Z \rightarrow Y$ yaitu $-0,437 \times 0,690=-0,301$. Besarnya pengaruh tidak langsung masih lebih besar dibandingkan dengan pengaruh langsung sebesar -0,094 yang berarti bahwa variabel $Z$ dapat menjadi variabel intervening. Hasil uji pengaruh antara work family conflict terhadap komitmen organisasional (t-statistics $=3,742>1,96$ ) dan pengaruh antara komitmen organisasional terhadap kinerja ( $t$-statistics $=8,870>1,96$ ) yang disimpulkan signifikan, sementara itu untuk pengaruh work family conflict terhadap kinerja yang disimpulkan tidak signifikan. Hasil pengujian menunjukkan bahwa komitmen organisasional merupakan variabel intervening pada hubungan pengaruh antara work family conflict terhadap kinerja yang bersifat full mediation.

\subsection{Pembahasan}

\subsubsection{Pengaruh Work-Family Conflict Terhadap Kinerja}

Work-family conflict disimpulkan memiliki pengaruh positif tetapi tidak signifikan terhadap kinerja. Hal ini menunjukan bahwa kenaikan atau penurunan yang terjadi pada variabel work-family conflict kurang berpengaruh terhadap variabel kinerja. Oleh sebab itu, hipotesis pertama yang menyatakan bahwa work-family conflict berpengaruh signifikan terhadap kinerja tidak dapat diterima. Berdasarkan hasil penelitian, work-family conflict pada perawat wanita di RSUD Bhakti Dharma Husada yang menjadi responden penelitian ini adalah tergolong dalam kategori rendah, hal ini didukung dengan nilai t-statistics $0,988<$ 1,96. Dengan work-family conflict yang dirasa rendah tersebut ternyata tidak menimbulkan kinerja yang cukup pada perawat wanita di RSUD Bhakti Dharma Husada. Hal ini berarti kinerja yang ditunjukan oleh perawat tidak berkaitan dengan konflik yang timbul dari keluarga. Hasil menunjukan secara keseluruhan, work-family conflict pada perawat wanita di RSUD Bhakti Dharma Husada yang menjadi responden penelitian adalah tergolong dalam kategori rendah, hal ini didukung dengan nilai t-statistics 0,988<1,96. Dengan work-family conflict yang dirasa rendah tersebut ternyata tidak menimbulkan kinerja yang cukup pada perawat wanita di RSUD Bhakti Dharma Husada. Hal ini berarti kinerja yang ditunjukan oleh 


\section{Jurnal Manajemen Teori dan Terapan \\ Tahun 7. No. 3, Desember 2014}

perawat, tidak berkaitan dengan konflik yang muncul dari keluarga sehingga berpengaruh terhadap pekerjaan. Kebutuhan untuk berhasil dalam pekerjaan dan keluarga dapat mengurangi terjadinya konflik pekerjaan keluarga pada perempuan menurut Higgins et al (1994). Ini menunjukkan bahwa perawat wanita di RSUD Bhakti Dharma Husada memiliki kinerja yang baik pada organisasi tanpa memandang konflik yang dimunculkan dari keluarga yang diterima. Bukti bahwa kinerja perawat wanita yang baik dapat dilihat dari rata - rata jawaban kinerja yang berada pada kategori sangat tinggi.

\subsubsection{Pengaruh Work-Family Conflict Terhadap Kinerja Dengan Komitmen Organisasional Sebagai Variabel Intervening}

Work-family conflict memiliki pengaruh tidak langsung terhadap kinerja karyawan, sebab harus melalui komitmen organisasional terlebih dahulu. Work-family conflict memiliki pengaruh langsung terhadap komitmen organisasional, dimana nantinya komitmen organisasional yang dipengaruhi oleh work-family conflict ini dapat berpengaruh terhadap kinerja. Oleh sebab itu, maka dapat dinilai bahwa komitmen organisasional mampu menjalankan peran sebagai variabel intervening dalam penelitian ini. Hasil uji pengaruh antara work family conflict terhadap komitmen organisasional (t-statistics $=3,742>1,96$ ). maka dapat dipahami bahwa work-family conflict memiliki pengaruh signifikan terhadap terhadap komitmen organisasional. Di samping itu, perlu diketahui pula bahwa pengaruh antara komitmen organisasional terhadap kinerja (t-statistics $=8,870>1,96$ ), maka dapat dipahami bahwa komitmen organisasional memiliki pengaruh signifikan terhadap terhadap kinerja. Pandangan tersebut didukung dengan kenyataan bahwa work-family conflict memiliki pengaruh signifikan terhadap komitmen organisasional dan juga komitmen organisasional yang memiliki pengaruh signifikan terhadap kinerja. Secara keseluruhan, dapat dilihat bahwa hipotesis kedua yang menyatakan Work-family conflict berpengaruh signifikan terhadap kinerja perawat wanita di RSUD Bhakti Dharma Husada dengan komitmen organisasional sebagai variabel intervening, dapat diterima.

Hasil yang telah dipaparkan tersebut berbeda dengan hasil penelitian yang dilakukan oleh Harijanto, Nimran, Sudiro, dan Rahayu (2013). Penelitian yang dilakukan oleh Harijanto, Nimran, Sudiro, dan Rahayu (2013), mengemukakan bahwa komitmen organisasi tidak mempunyai peran signifikan sebagai variabel intervening antara work-family conflict terhadap kinerja. Secara garis besar, dari penjelasan diatas dapat disimpulkan bahwa terdapat pengaruh work-family conflict terhadap kinerja melalui komitmen organisasional. Work-family conflict memiliki hubungan signifikan dengan komitmen organisasi. Dengan kata lain, semakin rendah work-family conflict, itu menyebabkan kenaikan komitmen organisasional. Hal ini dapat dijelaskan oleh hasil penelitian yang menyebutkan bahwa perawat telah mencapai zona aman sehingga mereka mengalami konflik peran yang rendah dan mereka masih tetap berkomitmen terhadap organisasi tempat mereka bekerja. Berdasarkan data yang telah terkumpul dapat diketahui sebagian besar perawat wanita di 


\section{Ahmad Hilmy Mubassyir Nuri Herachhwati}

RSUD Bhakti Dharma Husada memiliki masa kerja lebih dari 2-5 tahun, hal ini dikarenakan RSUD Bhakti Dharma Husada merupakan rumah sakit milik pemerintah kota Surabaya sehingga bagi perawat yang bekerja disana secara tidak langsung sudah menjadi pegawai negeri, menjadi pegawai negeri merupakan keinginan bagi perawat. Disamping itu secara umum perawat memiliki keinginan untuk tetap bekerja di RSUD Bhakti Dharma Husada, tidak memikirkan untuk dapat bekerja di rumah sakit lain dan akan berusaha untuk dapat berbuat yang terbaik bagi rumah sakit. Karena dengan adanya komitmen organisasional akan membuat para perawat mencurahkan semua kemampuannya untuk memberikan kontribusi terbaik bagi organisasi, memberikan pelayanan yang terbaik untuk para pasien, dan selalu berusaha memberikan dampak yang positif untuk kesembuhan pasien. Mayer et al (1990:152) menyatakan bahwa "terdapat hubungan antara komitmen organisasi dengan kinerja individu karyawan". Dengan demikian komitmen organisasi sangat penting dan membawa dampak yang besar bagi organisasi ataupun perusahaan. Karena dengan adanya komitmen organisasi akan membuat karyawan lebih mencurahkan semua kemampuannya untuk memberikan kontribusi terbaik bagi organisasi. Dengan demikian, perawat yang berkomitmen kepada organisasi akan memberikan suatu keunggulan tambahan dan berusaha dengan segala upaya bagi organisasi. Sehingga hal tersebut mampu mendorong peningkatan kinerja perawat secara keseluruhan serta berdampak pula pada tercapainya tujuan organisasi.

\section{Simpulan dan Saran \\ 5.1 Simpulan}

Berdasarkan hasil penelitian yang dilakukan, maka dapat diperoleh simpulan sebagai berikut:

1. Pengaruh secara langsung variabel work-family conflict $(X)$ terhadap variabel kinerja (Y) adalah tidak signifikan maka dengan ini hipotesis pertama yang menyatakan Work-family conflict berpengaruh langsung dan signifikan terhadap kinerja perawat wanita di RSUD Bhakti Dharma Husada ditolak.

2. Pengaruh secara tidak langsung variabel work-family conflict $(X)$ terhadap variabel kinerja $(Y)$ melalui variabel intervening komitmen organisasi $\left(Z_{1}\right)$ adalah dengan hasil signifikan antara work-family conflict dengan komitmen organisasional dan hasil signifikan antara komitmen organisasional dengan kinerja maka dengan ini hipotesis kedua yang menyatakan bahwa Work-family conflict berpengaruh signifikan terhadap kinerja perawat wanita di RSUD Bhakti Dharma Husada dengan komitmen organisasional sebagai variabel intervening diterima.

\subsection{Saran}

Berdasarkan hasil penelitian pada pembahasan dan kesimpulan, adapun saran yang dapat diberikan adalah sebagai berikut:

1. Perawat wanita RSUD Bhakti Dharma Husada sebaiknya mempertahankan komitmennya terhadap organisasi agar kinerjanya dapat terus meningkat sehingga dapat mencapai target sesuai dengan visi dan misi RSUD Bhakti Dharma Husada. Ada beberapa cara yang bisa ditempuh diantaranya perawat harus lebih aktif 
dalam kegiatan suatu organisasi dan memiliki tanggung jawab yang tinggi terhadap kewajibannya dalam organisasi sebagai perawat.

\section{Daftar Referensi}

Allen, T. D., D. E. L Herst, C. S Bruck \& M. Sutton. 2000. Consequences Associated With Workto-Family-Conflict: A Review and Agenda for Future Research. Journal of Occupational Health Psychology. Vol. 5 No. 2, p. 278-308.

Amstrong, Michael. 1999. The Art of HRD: Human Resource Management, Vol. 2 London: Crest Publishing House.

Arikunto, Suharsimi. 1992. Prosedur Penelitian Suatu Pendekatan Praktik. Jakarta: Rineka Cipta.

Bernardin, H. John and Joyce, E.A. Russel. 2000. Human Resource Management, Alih Bahasa Diana Hertati. Mc. Graw Hill, Inc. Singapura.

Choi, H. J. 2012. Work-family conflict, work-family facilitation, and job outcomes in the Korean hotel industry. International Journal of Contemporary Hospitally Management Vol. 24 No. 7, p. 1011-1028.

Frone, M. R. Rusell, M. \& Cooper, M. L. 1992, Antecedents and Outcomes of Work-Family Conflict: Testing a Model of The Work-Family Interface, Journal of Applied Psichology, Vol. 77 No. 1, p. 65-78.

Frone, M. R. 2003. Work-Family Balance', in J.C. Quick and L.E. Tetrick (eds) Handbook of Occupational Health Psychology. Washington, DC:APA Press.

Gomez, Cordosa. 2000. Manajemen Sumber Daya Manusia. Yogyakarta: Andi Offset.

Greenhaus \& N. J Beutell. 1985. Sources of Conflict between Work and Family. The Academy of Management Review Vol. 10 No. 1, p. 76-88.

Greenhaus., A. Z Stoeva \& R. K Chiu. 2002. Negative Affectivity, Role Stress, and Work-Family Conflict. Journal of Vocational Behaviour Vol. 60, p. 1-16.

Hasibuan, Malayu S. P. 2005. Manajemen Sumber Daya Manusia. Jakarta: Bumi Aksara.

Harijanto, Djoni. 2013. The Influence of Role Conflict and Role Ambiguity on The Employee's Performance Through Commitment and Self- Efficacy (Study on the Nurses at Public Health Service Center of Kabupaten Kediri, East Java. Journal of Business and Management Vol. 8 No. 1, p. 98-105.

Hellriegel Don \& J. W Slocum. 2004. Organization Behaviour 10th edition. Ohio: Thomson Learning.

Latifah, Ifah. 2008. Pengaruh Konflik Pekerjaan Keluarga Terhadap Turnover Intentions dengan Kepuasan Kerja Sebagai Variabel. Tesis. Program Studi Magister Akuntansi Universitas Diponegoro.

Meyer, I. P., \& Allen, N. J. 1990. The Measurement and Antecedents of Affective, Continuance and Normative Commitment to Organization. Journal of Occupational Psychology. New york. 


\section{Ahmad Hilmy Mubassyir \\ Nuri Herachhwati}

Mitchel T.R., 1982. People in Organization : in Introduction to Organization Behavior, MC.Graw Hill Book Comp. Tokyo

Mowday, R.T, Porter, L.W dan Steers R.M. 1982. Employee Organization Lingkages: The Psychology of Commitment, Absenteeism and Turnover. London: Academic Press Inc.

Mubassyir, Ahmad Hilmy dan Nuri Herachwati, 2015. Pengaruh Work-Family Conflict Terhadap Kinerja Perawat Wanita Melalui Variabel Intervening Komitmen Organisasional di Rumah Sakit Umum Daerah Bhakti Dharma Husada Surabaya, Program Studi S1 Manajemen Fakultas Ekonomi dan Bisnis Universitas Airlangga, 117.

Netemeyer, R. G., Maxham, J. G., \& Pullig, C. 2006. Conflicts in the work-family interface: Links to job stress, customer service employee performance, and customer purchase intent. Journal of Marketing, Vol. 69, p.130-143.

O' Reilly, C.A. 1989. Corporation's culture and commitment: Motivation and social control in organizations. California Management Review, Vol. 31 No. 4, p. 9-25.

Oomens. S., Genets. S. and Scheepers. P. 2007. Combining work and family in the Netherlands: Blessing or burden for one's mental health?. International Journal of Law and Psychiatry, Vol. 30, p. 369-384.

Rini, Jacinta F. 2002. Stress Kerja. Retrieved from:http://www.epsikologi.com/epsi/industri_detail.asp?id-172 diakses 12 Januari 2015.

Rivai dan Sagala Jauvani. 2010. Manajemen Sumber Daya Manusia Untuk Perusahaan (2th ed). Jakarta : Rajawali Pers

Sandroto, Christine Winstinindah, Megawati Oktorina, dan Indah Mula. 2010. Pengaruh Konflik Pekerjaan dan Konflik Keluarga Terhadap Kinerja dengan Konflik Pekerjaan Keluarga Sebagai Variabel Intervening: Studi pada Dual Career Couple di Jabodetabek. Jurnal Manajemen dan Kewirausahaan Vol. 12 No. 2, p. 121-132.

Sedarmayanti. 2001. Sumber Daya Manusia dan Produktivitas Kerja. Jakarta: Mandar Maju.

Sekaran, Uma. 2006. Metode Penelitian Untuk Bisnis. Jilid 1 Edisi 4. Jakarta: Salemba Empat.

Siwi, Tri. 2005. Pengaruh Komitmen Profesi, Partisipasi Anggaran, dan Self Efficacy Terhadap Konflik Peran Studi Empiris Pada Wanita Karir di Yogyakarta. Simposium Riset Ekonomi II, November 2005, ISEI, P. 1-12.

Smith, C \& Elloy, D. F. 2004. Antesedents of work-family conflict among dual-career couples: An Australian Study. Cross Cultural Management, Vol. 11 No. 4, p.17-27 